\title{
Memorial narratives and symbolic images as a resource for the development of Northern urban space
}

\author{
Irena Khokholova ${ }^{1 *}$, Natalia Danilova ${ }^{2}$, Alyona Tomaska ${ }^{2}$, and Kyunney Pestereva ${ }^{1}$ \\ ${ }^{1}$ M. K. Ammosov North-Eastern Federal University, 58, Belinskogo str., Yakutsk, 677007, Russia \\ ${ }^{2}$ Institute of Humanities and Problems of the Peoples of the North SB RAS, 1, Petrovskogo str., Yakutsk, 677027, Russia
}

\begin{abstract}
The article is devoted to the identification of symbolic markers and perception of the cognitive model of the space of the northern cities of the Republic of Sakha (Yakutia). The definition of "northern cities" is constructed based on the results of a study to identify various aspects of identity (national, territorial, ethnocultural) and is used by the authors when defining all cities of Yakutia. The main tools for constructing and regulating the cognitive map of a city are city monuments associated with historical memory and acting as components of state policy and a nation-building tool. The main research methods were historical and cognitive analysis and the method of questionnaire survey. The novelty of the article is a cross-cultural study of the perception of urban monuments as symbolic markers of urban space. The authors observe a difference in the perception of the symbolism of urban space between generational groups. It is concluded that each city, depending on its geographical and economic location, local characteristics, and national identity, has its own specific set of symbolic markers in the cognitive map of the city. The findings will contribute to the systematic study of the value attitudes of residents of modern Russian cities. Multilevel models of symbolic images associated with both national and territorial identities are being built.
\end{abstract}

\section{Introduction}

The city in its potential provides a dynamic course of economic, political, socio-cultural, communication, microevolutionary and other processes, acting as a matrix for the life arrangement and life support of citizens. Various socio-economic, political, and cultural factors influence the formation of the city's image. An important factor can be considered the potential contained in the cultural and symbolic sphere of urban space, which is demonstrated through various "city texts". According to D.N. Zamyatin and others, any city offers, as a rule, a multitude of symbolic images of different genesis, content, and structure, formed both by social and professional groups, and by individuals in the process of their purposeful activity [1]. These images can be presented as iconic symbolic markers of urban space.

\section{Materials and methods}

The theoretical and methodological basis was the work of famous Russian scientists representing the MoscowTartus semiotic school [2,3], and the concepts of modern cross-cultural research were used. In particular, the concept of historical memory (place of memory) by Pierre Nora, conceptual provisions aimed at studying the socio-cultural life of the city and involving citizens in the process of modeling symbolic urban space, urban identity and territory $[4,5,6]$. To develop the concept of this article, theoretical articles by D.N. and N.Yu. Zamyatin and I.I. Mitin allows a methodological basis built for the presentation of the city as a text and the city as a symbolic space [7].

According to Yu.M. Lotman, the city is a complex semiotic mechanism, which is a "cauldron" of texts and codes, diverse and heterogeneous, belonging to different languages and levels [2]. V.N. Toporov includes in the concept "city text" all the information that streets, squares, gardens, monuments, buildings, townspeople, etc., openly or implicitly give us and "can be understood as a heterogeneous text to which a certain meaning is attributed and on the basis of which the system of signs realized in the text can be reconstructed" [3].

The city becomes a "place of memory", a focus of significant events, a repository and reproduction of historical memory. Historical memory is supported primarily by the cultural heritage embodied in material objects that become "places of memory". "Place of memory" embodies the unity of the spiritual and the material, which, over time, was preserved and passed from generation to generation through a remembering culture, becomes a symbolic element of the cultural and historical heritage [8]. Thus, the memory of the city is considered as a mechanism for preserving, broadcasting and reproducing the past socio-cultural experience of urban life for the construction of being in the present [9]. M. Castells argued that «there can be no spatial theory

\footnotetext{
Corresponding author: iskhokholova@ mail.ru
} 
that would not be an integral part of the general social theory» [10]. He was supported by R. Ledrut and noted: «the city does not matter in itself, outside of the practice in which people participate at a certain time and in a certain place» [11].

Group self-identification is carried out not only with the help of official political, but also recognizable symbols that are significant for the community. These symbols are monuments, architectural structures, art objects, etc. Opportunities for interaction between the elite and society are often seen through the attitude of the authorities towards them.

The collection of primary sociological information on the RFBR and EISR project "The Symbolic Space of Northern Cities of the Republic of Sakha (Yakutia) in the Context of Socio-Political Processes" was carried out by a questionnaire survey of the urban population in 13 cities of the Republic of Sakha (Yakutia) $(n=919)$. A questionnaire survey on 2 thematic blocks: the role of the modern symbolic space of the cities of the Republic of Sakha (Yakutia) on the formation of political and national identity was carried out in September-December 2020. In accordance with the established sample, the questionnaire survey covered the population aged 18 years and older. The ethnic composition of the respondents is as follows: Sakha - 52.3\%, Russians $40.6 \%$, indigenous peoples of the North - 2.3, other nationalities - 1.8 , mestizos $-0.2 \%$, did not indicate nationality $-2.7 \%$.

\section{Results}

According to 2020, Yakutia includes 54 urban settlements, including: 13 cities, among which there are 4 cities of republican subordination, of which 1 city of republican significance - Yakutsk, the capital of the Republic. 3 cities are of republican subordination within the districts (Mirny, Nyurba, Pokrovsk); 9 cities of district (ulus) subordination; 41 urban-type settlements. The cities of Yakutia can be conditionally divided into the following districts according to several distinctive features into the oldest cities (Yakutsk, Vilyuisk, Verkhoyansk, Srednekolymsk, Olekminsk) and industrial cities (Neryungri, Aldan, Tommot, Lensk, Mirny, Udachny, Pokrovsk, Nyurba), northern cities (Verkhoyansk and Srednekolymsk). All northern cities have their own rich history, cultural heritage, in addition, they are symbolic centers of industrial development of the Permafrost territory. For example, Mirny is considered the "diamond capital", Neryungri is the "coal capital", Aldan is the "golden" province of Russia, and the oldest city Verkhoyansk, founded in 1638 as the Verkhoyansk prison, received the status of a city in 1822 and is the northernmost city and the center of the Pole of Cold. Northern cities in their potential provide a dynamic course of economic, political, socio-cultural, communication, microevolutionary and other processes, acting as a matrix for the life arrangement and life support of citizens in the harsh climatic conditions of the North.

In the context of modernization processes and globalization, the preservation and study of the ethnic specifics of the carriers of the "living traditional culture" is becoming one of the important factors in the implementation of socio-cultural policy. Today, there is a gradual understanding of cultural heritage not only as a system of spiritual values, but also as an image tool that can influence the development of the region. According to the results of questionnaire and spontaneous surveys, the presentation of the cultural heritage of the indigenous peoples of the North (Yakuts, Evens, Evenks, Yukagirs, Dolgans) is considered a promising direction in the republic and the formation of a new positive assessment scale for the perception of the image of the territory as a whole $(98.0 \%)$ and the formation of national identity $(86.0 \%)$.

It is known that cultural and symbolic capital is mainly concentrated in rural settlements. Nevertheless, in recent decades, in many Russian cities, including in the cities of Yakutia, significant progress has been made in organizing the urban landscape using the ethnocultural potential, which shows that the urban population is quite adaptive to the political and socio-cultural changes that have taken place. Thus, the revival of national culture in the 90 s of the twentieth century gave an impetus to the formation of a fundamentally new attitude to cultural heritage as a source of social, cultural and economic development of the region. In this context, special attention should be paid to symbolic images that construct and form the modern cultural environment (development resource) in the urban space and represent ethno-cultural brand codes: for example, in a questionnaire survey, respondents indicate such monuments as "Bull of Winter" - a symbol of Cold, "Peak of Cold" (Verkhoyansk), "Olonkhosut" (Mirny), "Kayury" (Neryungri), etc.

\subsection{Symbolic images of the "North"}

At the beginning of the XXI century, when the Russian regions made a qualitative leap in the implementation and development of socio-cultural projects, and the projects themselves became an effective tool for the development of territories, new cultural identity codes are being constructed. As a result of the actively pursued image policy in the republic to promote a positive image of the Pole of Cold, the geocultural concepts "cold", "north", "winter" become a brand tool and as metaphorical images experience a "second birth". The cold climate of the region began to be perceived as a source of additional benefits and opportunities for humanity and a healthy lifestyle, and the old stereotypical ideas that developed in the era of tsarist power, as about "the land of eternal winter and cold", "prison without bars", and in Soviet times "the north - as a raw material appendage" and "bear corner", began to leave the general perception of the Yakut region. Thus, the historical and cultural landscape as a panorama forms a "permanent space" and serves as an ideal position for seeing the world [12].

The promotion of the theme of Eternal cold, the positive brand of "Winter" on the world market contributed to the emergence of a new festival "Winter 
begins with Yakutia", which brings together all Santa Claus, Ded Moroz, etc., to light the first Christmas tree on December 1 on the main square of Yakutsk. The Lord of winter and cold Chyshaan, developed by the creative intelligentsia and became the modern embodiment of the mythical image of the Bull of Winter, has become a national winter brand in Russia.

In the socio-cultural space of Yakutsk city, a metaphorical image of the center of the Arctic space is gradually introduced. So, in Yakutsk, the Arctic State Institute of Culture and Art and the Arctic Research Center appeared, the Yakutsk State Agricultural Academy was renamed the Arctic State Agrotechnological University, the construction of the Arctic Center of Epos and Culture is planned, etc.

The image of the North/Cold received a second wind in the rebranding system "Yakutia - the country of permafrost", in which natural and climatic conditions become one of the main tools for constructing figurative and geographical models. Today, the cognitive perception of Verkhoyansk city is associated with the Cold Pole, and Srednekolymsk is represented as a topos, where the Arctic begins. In this context, the image of Yakutia for the development of extreme, ethnic and event tourism is actively promoted.

It would seem that the symbolic capital constructed within the framework of the new image and cultural policy could lay the foundation for the formation of the northern identity among the population of Yakutia, however, the results of the conducted sociological research showed a different result. So, among the indigenous population, regardless of nationality, "northerners" consider themselves only residents of the northern regions and the alien population, for whom the whole Yakutia is associated with the image of the North and is perceived as the Northern Region. $80.0 \%$ of the respondents of the Yakut nationality in the collective image of "their land" intertwine the image of the southern ancestral homeland, as the metaphor of the South as a "figure of memory" is translated throughout the cultural model of the Sakha people.

Thus, the concept of cultural heritage in different versions is considered as a product of the development and transformation of the urban landscape and a factor in the formation of national and territorial identity.

An important factor in the development of urban space can be considered the potential contained in memorial narratives that represent various significant events and personalities, urban mythopoetics, and ethnocultural representations. In this regard, it is advisable to turn to the study of the objects of commemoration of urban space. The main attention was paid to the monuments, since it is through them that the nationbuilding landmarks (historical and cultural memory, identity, value landmarks) are reflected.

\subsection{Memorial narratives of urban space}

Information about the past and significant events of the country is broadcast to the population through the monuments. A survey in the cities of Yakutia showed that $63 \%$ of the towns inhabitants are interested in the country's politics, and only $54.4 \%$ are interested in the history of the republic, which shows that the level of interest is not high enough. At the same time, $67 \%$ of the respondents know in honor of which event or historical figure the monument was erected. In one question, the respondents were asked to name prominent figures of importance for Yakutia, 93\% of the respondents named the figures of the Soviet era, only $6.6 \%$ of the answers mentioned modern politicians of Yakutia. $49 \%$ of the inhabitants see the Lenin monument as a symbolic center of the city, $23 \%$ - monuments to Yakut political representatives of the Soviet era, 15\% - monuments to Cossack pioneers, Victory monuments (Memorials of Glory) $-7.6 \%$. In the industrial cities of Yakutia, the concept "symbolic city space" is associated with the development of industry - the "Peace" memorial, etc. As the survey showed, the common history that the former Soviet republics went through is associated with key events in the history of the Soviet era (Revolution, Great Patriotic War, and others) and are factors in the formation of collective historical memory. Depending on the perception of the monument by the town inhabitants, it acquires its symbolic function, mythologeme and becomes an identifying marker of this locus. Meanwhile, not all monuments become iconic points. In Yakutsk, the following monuments were named as symbolic markers of the urban space by the majority of the surveyed citizens. The Monument to V.I. Lenin - the leader of the proletariat - 98\%. The Memorial complex on Victory Square (1970-2005) - 95\%. The Monument to the great son of the Yakut people P.A. Oyunsky is $80 \%$. The Monument to the state and public figure, one of the initiators of the Yakut autonomy M.K. Ammosov is $80 \%$. The Monument to the pioneer S.I. Dezhnev and his family is $78 \%$; the Monument to the Janitor (70\%); the Monument to the founder of the city P.I. Beketov (68\%); the Monument to Mother $(65 \%)$; the Monument to the founder of Yakut literature A.E. Kulakovsky (50\%); the Monument to Academician V.P. Larionov (45\%); the Monument to educator I. Veniaminov (35\%);

It should be noted that not a single city has memorial complexes dedicated to legendary heroes or folklore motives of the indigenous peoples of Yakutia. Nevertheless, individual ethnic motives are included in the general compositional structure of the monuments (hitching post-serge, deer, choron, sledges, etc.). According to the survey, $70 \%$ of respondents would like to see monuments with a pronounced ethnic orientation in their cities (the first ancestor of Ellei Botur, historical personality Tygyn Darkhan, sacred horse, sacred deer, Ysyakh motives, epic heroes like Nurgun Botur, Tuyaaryma Kuo, Yuren Khosun, etc.).

As an integral part of the brand and image of the urban space, $35 \%$ of respondents indicated monuments dedicated to historically significant events related to the industrial development of the territory (monuments dedicated to miners, geologists in the cities Neryungri, Mirny, Aldan, etc.). 35\% noted iconic personalities of ulus / district, "geniuses of the area" (a monument to N.G. Chernyshevsky in Vilyuisk, L. Petukhova in Nyurba, brothers Ksenofontov in Pokrovsk, etc.). And $40 \%$ marked local geocultural images (a monument to 
the Bull of Winter and the sign of the Pole of Cold in Verkhoyansk, for a mammoth in Srednekolymsk, for a diamond / brilliant in Mirny, etc.).

At the same time, the respondents indicated that monuments dedicated to residents, ordinary workers (a monument to a musher in Neryungri, an art object Dvornik in Yakutsk, etc.) and folk heroes (a monument to sniper Kulbertinov in Yakutsk, journalist N. Protopopova, art object "Doroobo" in Vilyuisk, etc.). So, for example, in Verkhoyansk, a sculptural monument dedicated to famous olonkho performer Daria Tomskaya-Chaika, the keeper of the local peculiarities of Verkhoyansk folklore, according to the majority of respondents $(75 \%)$ on the cognitive map of the city, began to occupy higher positions (although it was installed relatively recently in 2019) than the previous brand code of the city as the capital of the Pole of Cold, the mythological image of the Bull of Winter $(25 \%$ of the respondents).

If only historical memory is associated with monuments and memorials, then art objects and murals are a kind of author's representation of a modern vision of cultural heritage. Although street painting appeared all over the world in the 19th century, it has become popular in Russian cities, including Yakut ones, in the last 3-5 years. In Yakutia, not only in cities, but also in other settlements, they began to decorate the walls of buildings, which are mainly associated with both historical and cultural memory and local geocultural images. So, in Vilyuisk, a mural dedicated to Kate Marsden, the English sister of mercy, was realized; in Nyurba - the legendary founder of the Nyurba clans Nyrbakaan; images of the Arctic space and nomadic life - in Srednekolymsk; to the symbols of Yakut culture - a girl in traditional clothes and jewelry; to the symbolic elements of the Ysyakh holiday - a choroon, a sacred horse, a hitching post, etc. in Yakutsk.

\section{Conclusion}

The symbolic space of cities in the northernmost region the Republic of Sakha (Yakutia), which reveals different layers, different cultural levels, "pre-Soviet", "Soviet" and "global" - transnational layers, generally supports the image of a multiethnic region. The city-forming branch of the industrial northern region is expressed in the symbolic space of relatively young industrial cities that arose in the 20th century in connection with the development of resource components, economic and political development of the country.

Memorial complexes and monuments are cultural and symbolic objects that form, among other things, political identity, reflecting today the transformation of ideas about the region and serving as a resource for branding the territory. The symbolization of urban space is an integral part of the appropriation by the inhabitants of towns of certain elements that have a symbolic status. There is a difference in the perception of the symbolism of urban space between generational groups: youth (born in the post-Soviet era), middle and older generation (generation of the Soviet era), which is characterized by ignorance or forgetting of the country's historical events.

The significance of a monument as a tool and a symbolic marker of space, first, depends on the political context and its introduction into the collective memory through a constant "reminder" of its importance and significance in the socio-cultural and everyday life of the towns' inhabitants. In this connection, the urgent problem is the task of preserving the accumulated experience and values, places of memory, relics of the past, as well as ideas about the past that are stored in the memory of its inhabitants and the transfer of this knowledge to the younger generation.

\section{Acknowledgments}

The reported study was funded by RFBR and EISR according to research project No. 20-011-31324 "Symbolic space of the northern cities of the Republic of Sakha (Yakutia) in the context of socio-political processes" and also with the support of the Ministry of Education and Science of the Russian Federation within the framework of the Program of Fundamental and Applied Scientific Research of the Russian Academy of Sciences "Ethno-cultural diversity of Russian society and strengthening of the All-Russian identity" 2020-2022.

\section{References}

1. D.N. Zamyatin, Modeling images of a historical and cultural territory: methodological and theoretical approaches. (Moscow: Institute of Heritage, 2008)

2. Yu.M. Lotman, Semiosphere. Culture and explosion. Inside thinking worlds. Articles. Research. Notes (Sant-Petersburg: Art-SPB, 2000)

3. V.N. Toporov, Petersburg and the "Petersburg text of Russian literature". Myth. Ritual. Symbol. Image. Research in the field of mythopoetic. (Moscow: Progress-Culture, 1995)

4. V.L. Glazychev, Urban Studies (Moscow: Europe, 2008) Retrieved from: http://www.glazychev.ru/books/urbanistika/urban istika.htm

5. D.V. Vizgalov, Branding of the city. (Moscow: Institute for Urban Economics Foundation, 2011)

6. A. Filko, Sociodynamics, 7, 51 - 64, (2015)

7. N.Yu. Zamyatina, D.N. Zamyatin, I.I. Mitin, Modeling images of a historical and cultural territory: methodological and theoretical approaches. (Moscow: Institute of Heritage, 2008)

8. P. Nora, France - memory. (Sant-Petersburg: Publishing House of St. Petersburg University, 1999)

9. I.Yu. Solomina, Social memory and culture: archetype, monument, oblivion (Samara: Samara State Regional Academy, 2013)

10. M. Castells, La question urbaine. (Paris: François Maspero, 1972) 
11. R. Ledrut, Les images de la villes. (Paris: Editions Anthropos, 1973)

12. I. Svirida, Slavic world. (Moscow: ProgressTradition, 2007) 